\section{Staff pay cost of keeping CERN collider on target}

Munich. Officials at the European Laboratory for Particle Physics (CERN) in Geneva, Switzerland, say they will be able to build the Large Hadron Collider by 2005 as planned, despite the governing council's decision shortly before Christmas to accept a substantial budget cut.

This renewed commitment to the agreed timetable makes it almost certain that the United States will contribute towards the US\$2-billion cost of construction. And Japan announced at last month's council meeting that it was prepared to increase its planned contribution from $¥ 5$ billion to $¥ 8.85$ billion (US\$44 million to US\$78 million).

But the price of maintaining the commitment to complete construction in 2005 will be high. Staff will have to accept a pay cut, and there could be a five-year gap in highenergy physics experiments at the laboratory until the collider comes into operation.

CERN council agreed on a series of reductions to the laboratory's planned budget, which would otherwise have been kept reduced by 7.5 per cent below the 1996 level in $1997,8.5$ per cent below for the following three years, and 9.3 per cent after that.

These figures represent a slight compromise on a demand by the German government for an immediate cut of 8.5 per cent, and further cuts to reach the target of 9.3 per cent by 1999 (see Nature 382, 387; 1996). Member states promised not to force further cuts on CERN at least until the collider is operational. But the cuts will still require harsher belt-tightening than any Europeanlevel laboratory has previously experienced.

The basic salary of staff is being cut by 2.5 per cent this year (see Nature 384, 603; 1996). The provision for automatic indexlinking of salaries has been removed for 1998 and 1999. And a full review of the salary structure is being carried out to identify further ways to cut costs.

Christopher Llewellyn Smith, CERN's director-general, says that many weaknesses in the current salary structures add to the laboratory's costs. He says benefits for expaat a constant level. The budget will now be triates are too generous, and promotion for all staff is too automatic. He is confident economic situation in Europe", and will therefore accept the inevitability of cuts in salary and benefits.

One CERN researcher says the laboratory's staff are not expected to "go to the wall" from a 2.5 per cent budget cut. Any potential damage, he says, will come from the terms of the deal, such as the CERN council's decision to dip into a cash reserve intended to compensate for future inflation. "Inflation is low, but is likely to increase. Will council stump up the extra cash when this happens? I have my doubts."

The new budget means that CERN will have no cash available to support plans for additional high-energy particle physics experiments in the period between the switching off in 2000 of the current particle accelerator, the Large Electron-Positron Collider (LEP), and the operation of the Large Hadron Collider in 2005. Smaller high-energy physics programmes such as LEAR (the low energy antiproton ring) and the Omega spectrometer have been recently closed to help pay for the collider.

Llewellyn Smith wants member states to help solve this problem. CERN will have no capital to help, but it can provide old equipment and the infrastructure to support experiments if they can be paid for by national agencies. "Not all countries were in favour of the large reductions to the budget," he points out.

Amid the general gloom, Japan's news was encouraging. The council meeting was told that Japan, a non-member state, was prepared to increase its contribution to the collider which it agreed 18 months ago (see Nature 375, 169; 1995), subject to approval by the Japanese parliament, the Diet. According to the president of CERN, Hubert Curien, this provided an important psychological boost, as well as a financial boost. CERN hopes to find room for manoeuvre economically by attracting money from outside the organization.

Alison Abbott that "the majority of staff understand the

\section{Russian scientists name 'donor of the year'}

Moscow. The Russian Association for the Advancement of Science and Education, a body set up jointly in 1995 by Russian members of the European Academy and the Russian Academy of Sciences, has chosen prominent businessman Boris Berezovsky as its first 'philanthropist of the year' for his support for Russian science.

Berezovsky, currently deputy chairman

\section{Destruction order for transgenic crop after breach of guidelines}

New Delhi. Scientists at the Indian Agricultural Research Institute (IARI) have been told to destroy a transgenic vegetable crop after the Department of Biotechnology (DBT) alleged that the experiment was being carried out without its knowledge and in violation of safety guidelines.

This is the first time the department has taken action under the Environmental Protection Act of 1986, which prohibits unauthorized field trials of genetically manipulated organisms. Under the act, those who violate the department's guidelines on such research can be fined or sent to jail.

The IARI scientists, based in New Delhi, have introduced the toxin gene of Bacillus thuringiensis (Bt) imported from Japan into a native variety of brinjal (eggplant or aubergine). The aim is to make the brinjal resistant to insect attack.

But P. K. Ghosh, an adviser to the DBT, says the trial violated guidelines that prohibit open field experiments involving any transgenic crop without a permit. Such permits are issued by the department on the recommendation of a national panel that reviews research proposals for environmental and human safety. Only two permits have so far been issued for transgenic trials and IARI has not received either.

The department is concerned that insects and wind might spread pollen grains from the IARI's experimental plot to neighbouring fields and contaminate the wild relatives of the plant with the foreign gene. The department says that the institute should have conducted experiments in a glasshouse before going to the open field.

R. P. Sharma, head of the research team, says that the field was covered by a giant mosquito net to prevent insect pollinators from entering the trial plot. He says that, since no other brinjals were growing in the vicinity, the question of wind spreading the gene to wild relatives did not arise. But the department has told the scientists to destroy the crop immediately. It admits that it lacks details of experiments at ten other institutes to which IARI has supplied the imported gene. An institute in Simla, for example, which lacks the mandatory biosafety committee, has introduced the gene into potato plants. "We do not know if they are growing the plants in the laboratory or in the field," Ghosh says.

According to Ghosh, one research institute is growing genetically engineered cotton in the open without authorization. The department recently closed down an experiment at an institute in Chandigarh after it discovered that a cholera toxin gene was being handled without adequate safety containment.

K. S. Jayaraman 